\title{
First record of the Bermuda sea chub Kyphosus saltatrix (Pisces: Kyphosidae) in Greek waters
}

\author{
SOTIRIS KIPARISSIS, DIMITRIS LOUKOVITIS AND COSTAS BATARGIAS \\ Department of Aquaculture and Fisheries Management, Technological Educational Institute of Messolonghi, Nea Ktiria, 30200 \\ Messolonghi, Greece
}

\begin{abstract}
A single specimen of Bermuda sea chub Kyphosus saltatrix was caught in the Ionian Sea (western Greece). It is the first occurrence of this species in Greek waters and it constitutes its easternmost verified distribution in the Mediterranean. The specimen was a 4-year old male, fully adapted to benthic life and its occurrence adds to the increasing rate of detections of this species in the basin during the last decades.
\end{abstract}

Keywords: Kyphosus, Kyphosidae, Mediterranean, Ionian Sea, tropicalization, first record, mtDNA

Submitted 19 November 2011; accepted 9 December 2011

\section{INTRDロUCTION}

Bermuda sea chub Kyphosus saltatrix (Linnaeus, 1758) (last synonym: $K$. sectator), is a fish species widely distributed in the western Atlantic, extending from Canada in the north (Scott \& Scott, 1988) to Brazil in the south (Robins \& Ray, 1986), including the Gulf of Mexico and the Caribbean Sea (Cervigón, 1993). It is a gregarious shallow water herbivorous species with distinct dentition (hockey-stick shaped incisorlike teeth), which presents squamation on the soft parts of the dorsal, anal and caudal fins. It is also found in the eastern Atlantic, its northern distribution there being along the south Moroccan Atlantic coasts, extending southwards to the Gulf of Guinea (Desoutter, 1990). It is sporadically found in the Canary Islands, Azores and Madeira Islands (Almada et al., 1999). Up to date, there have been only five verified sightings north of the Atlantic Moroccan coasts: one sighting off the coast of the Algarve (Canas et al., 2005), one sighting in Galician waters (Bañon, 2004) and three sightings in the Bay of Biscay (references in Quéro et al., 2009). In the Mediterranean Sea it is quite rare (Tortonese, 1986), with its first validated record coming from a museum specimen caught in 1846 near Trieste (northern Adriatic). Its identity was confirmed by Dulčić \& Ahnelt (2006). Since 1846 there have been another five validated records along the northern Mediterranean coasts (Doderlein, 1884; Ariola, 1904; Merella et al., 1998; Francour \& Mouine, 2008; Ligas et al., 2011), and two records from the coasts of North Africa, one in Algeria (Hemida et al., 2004) and one in Tunisia (Hattour, 2006).

On 20 January 2011, a single specimen of K. saltatrix was caught in the Ionian Sea (western Greece). It is the first time

Corresponding author:

S. Kiparissis

Email: skiparis@teimes.gr this species has been detected in Greek waters and this constitutes its most eastern verified distribution in the basin to date. In this work we present its morphological and biological data, along with mtDNA analysis for future comparison with other specimens that may be found, or have been found, in other Mediterranean and north-eastern Atlantic areas.

\section{MATERIALS AND METHDDS}

\section{Morphology}

The specimen (Figure 1) was spearfished in the Strofades Islands (Figure 2) around midday. It was detected at about $16 \mathrm{~m}$ depth over rocky substratum covered with phaeophyceae, moving in midwater. Measurement of its morphometric characters and counting of its meristics were conducted while the fish was fresh. All measurements were conducted on the left side of the body and they represent the direct distances between points in accordance with Hubbs \& Lagler (1958). Apart from the overall length measurements that were recorded to the nearest $\mathrm{mm}$, all other measurements were recorded to the nearest $0.1 \mathrm{~mm}$ using callipers. Afterwards, the fish was dissected for further analysis. Stomach distension and perivisceral fat deposits were recorded and viscera were removed in order to examine stomach and intestine contents. The degree of stomach distension and perivisceral fat deposits were ranked according to the subjective indices of Lebedev (1946) and Prozorovskaya (1952) respectively. Gonad tissue was removed in order to verify its sex microscopically and otoliths were also removed for age determination. Age reading was conducted on the left sagitta, using reflected light against a dark background. Finally, after extracting tissue for DNA analysis, the specimen was immersed in a $4 \%$ formaldehyde solution for a couple of days and finally preserved in $70 \%$ alcohol. 


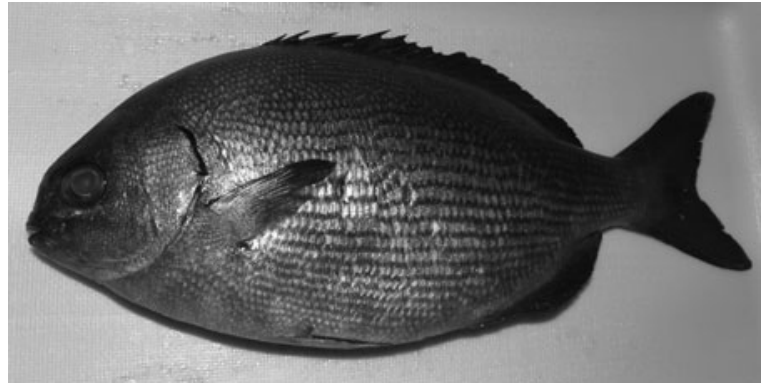

Fig. 1. The Kyphosus saltatrix specimen spearfished at Strofades Islands (Ionian Sea).

\section{Extraction of total DNA and amplification of mtDNA genes}

Genomic DNA was isolated from muscle tissue, by standard proteinase $K$ digestion, following the salting out procedure as described in Miller et al. (1988). The DNA concentration was adjusted to approximately $30 \mathrm{ng} \mathrm{\mu l}^{-1}$ through dilution with distilled water. Three mtDNA segments were amplified by polymerase chain reaction (PCR) using universal primers for cytochrome $b$ (L14841-H15149; Kocher et al., 1989), $12 \mathrm{~S}$ rRNA (12SAL-12SBH; Palumbi et al., 1991) and 16S rRNA (16SarL-16SbrH; Palumbi et al., 1991) segments. All PCRs were performed in $10 \mu \mathrm{l}$ volumes containing 0.04 units $\mu \mathrm{l}^{-1}$ of Taq polymerase (FINNZYMES, Espoo, Finland), $1 \times$ Taq buffer (magnesium free), $0.2 \mathrm{mM}$ dNTPs mix, $1.5 \mathrm{mM}$ $\mathrm{MgCl}_{2}, 0.5 \mu \mathrm{M}$ of each forward and reverse primer, and approximately $30 \mathrm{ng}$ of template DNA. Cycling conditions for PCR amplifications consisted of an initial $95^{\circ} \mathrm{C}$ denaturation step for 3 minutes followed by 35 cycles of 60 seconds at $94^{\circ} \mathrm{C}, 60$ seconds at $54^{\circ} \mathrm{C}$ (for cytochrome $b$ and $12 \mathrm{~S}$ rRNA) or $55^{\circ} \mathrm{C}$ (for $16 \mathrm{~S}$ rRNA), and 60 seconds at $72^{\circ} \mathrm{C}$, with a final extension at $72^{\circ} \mathrm{C}$ for 5 minutes. The resulting amplified DNA fragments were purified with the NucleoSpin ${ }^{\circledR}$ Extract II Kit (Macherey-Nagel, Düren, Germany) according to the manufacturer's protocol. The purified PCR products were sequenced (VBC-BIOTECH GmbH, Austria) and the sequences were deposited in GenBank with the Accession nos: JNo07798, JNo07799 and JNo07800 for 12S, 16S and cytochrome $b$, respectively. Finally, the sequences were submitted to the BLAST program in GenBank to compare them with other sequences deposited in public databases (Zhang et al., 2000).

\section{RESULTS}

\section{Morphology}

The meristics of our specimen were in accordance with those described by Tortonese (1986) for this species and they were within the range of counts given by other authors for their specimens, except for the number of anal fin rays: 10 in our specimen as compared to the 11 rays counted in all other specimens caught in the Mediterranean. The coloration of the specimen was dark-brown to olive in the upper half part of the body and lighter-brown in the lower half with faint yellow stripes along the scale series. The total length of the fish was $265 \mathrm{~mm}$ and it weighed 352.2 grams. Description of

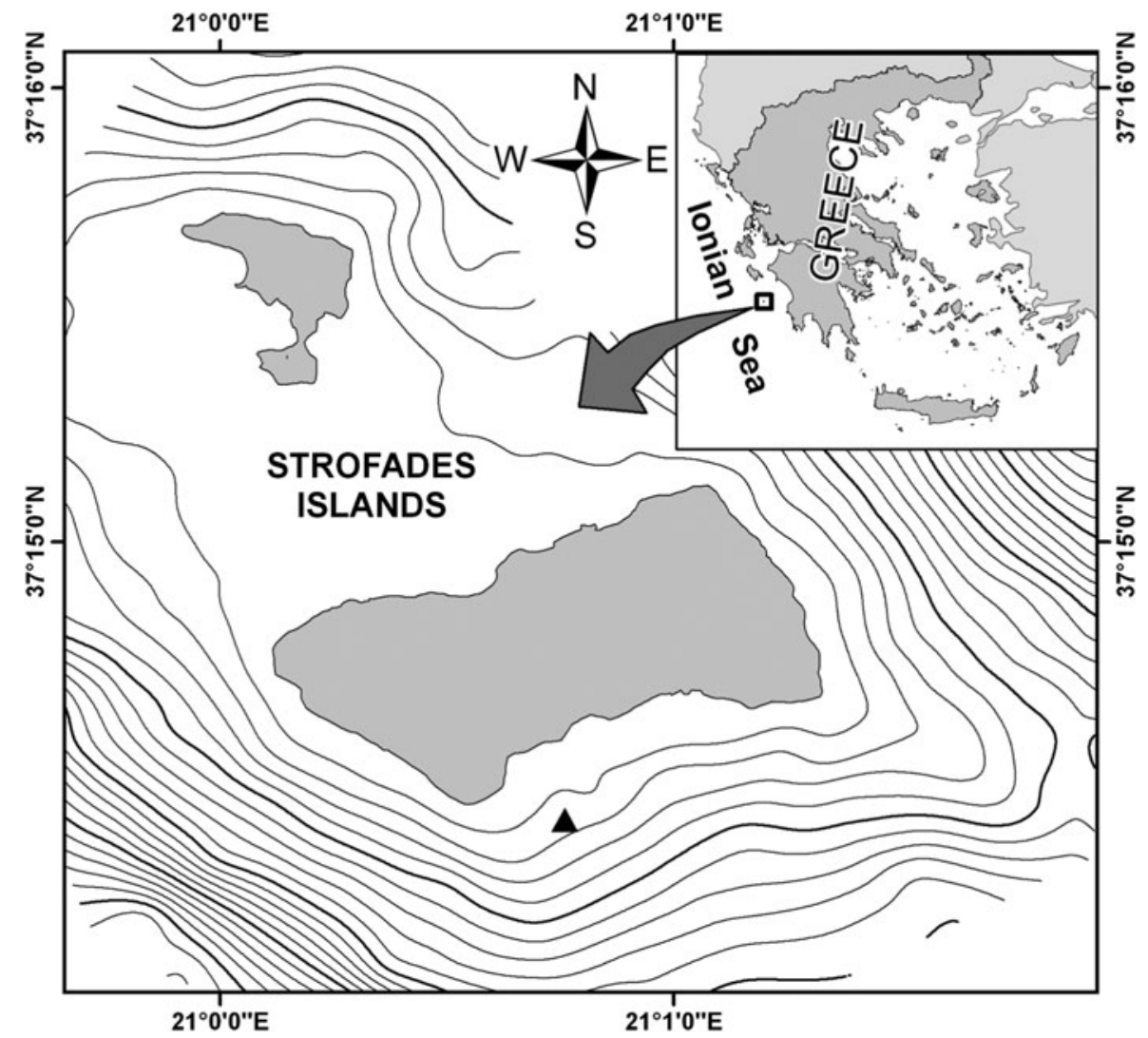

Fig. 2. Detection site of the Kyphosus saltatrix specimen at Strofades Islands. The site is denoted by the solid triangle. Contour lines represent $10 \mathrm{~m}$ isobaths. 
the meristics and values of the morphometric parameters examined are summarized in Table 1 and Table 2 respectively. Body and head measurements are presented both as direct measurements and as percentages of the standard length (SL) and head length (HL) respectively.

In the upper jaw, besides the well formed regularly spaced incisor-like teeth, there were also two other tooth types in the posterior margins of the premaxillar bones that were not included in the counting. The first type comprised six polycuspid incisor-like teeth irregularly arranged in the left premaxillary, next to the row of the regular teeth. The second type comprised very small conically pointed teeth embedded in the skin, irregularly spaced in the outer margins of the premaxillar bones. There were seven such teeth on each side. A band of such teeth was also observed behind the front row of the hockey-stick shaped regular teeth. None of the above irregular tooth types were detected on the dentary.

The stomach of the specimen was quite distended (degree 3 in Lebedev's scale: stomach filled in about half its maximum distension ability), containing exclusively plant material. The largest proportion of the stomach content was undigested, providing evidence that the fish foraged during daytime and the existence of exclusively plant material in the stomach proves that the specific individual had fully adopted a benthic lifestyle. Its intestine was quite long $(572 \mathrm{~mm}, 2.74$ times its SL), a typical trait of herbivorous species, and fully digested material was found all along its length.

Perivisceral fat deposition was in the form of a long strip, spreading from the anus to the entire length of the intestine, ranked as unit 2 in Prodorovskaya's fat-deposition grading scale. Microscopic inspection of the gonad revealed that the specimen was an immature male (maturity Stage I, after the classification proposed by Nikolsky (1963)).

Reading on the left sagitta of the specimen revealed four completed translucent bands (representing periods of slow growth), indicating an age of $4+$. Due to the lack of other specimens we were unable to conduct marginal increment analysis in order to verify the periodicity of the ring formation, so at the moment we consider that the detected rings represent annual rings, which is the most common case for fish living in the Mediterranean.

\section{Sequence alignment and comparisons}

The length of the amplified product was 390, 460, and $690 \mathrm{bp}$ for cytochrome $b, 12 \mathrm{~S}$ and $16 \mathrm{~S}$ rRNA, respectively. The query

Table 1. Descriptions and counts of the meristic parameters of the Kyphosus saltatrix specimen caught in the Ionian Sea.

\begin{tabular}{ll}
\hline Meristic parameter & Counts \\
\hline Dorsal fin spines + rays & XI +11 \\
Anal fin spines + rays & $\mathrm{III}+10$ \\
Pectoral fin rays & 18 \\
Pelvic fin rays & $\mathrm{I}+5$ \\
Caudal fin rays & 18 \\
Pored scales in lateral line & 55 \\
Scale rows above lateral line to the dorsal fin origin & 12 \\
Scale rows below lateral line to the anal fin origin & 20 \\
Gill rakers on 1st arch (upper + lower branch) & $7+18$ \\
Incisor-like teeth on upper jaw (fully formed) & 25 \\
Incisor like teeth on lower jaw & 25 \\
\hline
\end{tabular}

length was $307 \mathrm{bp}, 396 \mathrm{bp}$ and $570 \mathrm{bp}$ for cytochrome $b, 12 \mathrm{~S}$ and $16 \mathrm{~S}$ rRNA, respectively, after the sequences read from both sides were aligned and trimmed of primers.

There was no other sequence deposited in GenBank for Kyphosus saltatrix. However, there were a limited number of sequences deposited for blue sea chub Kyphosus cinerascens (Forsskål, 1775), for brassy chub Kyphosus vaigiensis (Quoy \& Gaimard, 1825) and for blue-bronze sea chub Kyphosus analogus (Gill, 1862), for these three mitochondrial genes. For the cytochrome $b$ the similarity was $94 \%$ with $K$. cinerascens (1 sequence deposited). For the $12 \mathrm{~S}$ rRNA gene the similarity was $97-98 \%$ with $K$. cinerascens (2 sequences deposited) and $94-97 \%$ with $K$. vaigiensis (3 sequences deposited). Finally, the similarity for the $16 \mathrm{~S}$ rRNA gene was $98 \%$ with $K$. cinerascens (3 sequences deposited), 97\% with $K$. vaigiensis (3 sequences deposited) and $94-97 \%$ with $K$. analogus (2 sequences deposited).

\section{DISCUSSIDN}

Despite its abundance in tropical and subtropical Atlantic areas, K. saltatrix is not very well studied and few data on

Table 2. Morphometric data of the Kyphosus saltatrix specimen caught in Ionian Sea. Body and head measurements are presented also as percentages of the total length (TL) and the head length (HL) respectively.

\begin{tabular}{|c|c|c|c|}
\hline Parameter & Size $(\mathbf{m m})$ & $\% \mathrm{SL}$ & $\% \mathrm{HL}$ \\
\hline Total weight & $352.2 \mathrm{~g}$ & & \\
\hline Eviscerated weight & $318.8 \mathrm{~g}$ & & \\
\hline Total length (TL) & 265 & & \\
\hline Fork length (FL) & 234 & & \\
\hline Standard length (SL) & 209 & & \\
\hline Head length (HL) & 54.1 & 0.26 & \\
\hline Head depth at the end of operculum & 81.1 & & 1.50 \\
\hline Head depth at the end of orbit & 48.9 & & 0.90 \\
\hline Head width (at operculum) & 34.6 & & 0.64 \\
\hline Orbit diameter (horizontal) & $14 \cdot 3$ & & 0.26 \\
\hline Orbit diameter (vertical) & 12.8 & & 0.24 \\
\hline Eye diameter & 11.7 & & 0.22 \\
\hline Inter-orbital space & $24 \cdot 3$ & & 0.45 \\
\hline Pre-orbital length & 10.9 & & 0.20 \\
\hline Post-orbital length & 26.7 & & 0.49 \\
\hline Body width at dorsal origin & 39.1 & 0.19 & \\
\hline Body width at anal origin & 29.3 & 0.14 & \\
\hline $\begin{array}{l}\text { Body depth measured at the level of the } 6 \text { th } \\
\text { dorsal spine (maximum depth) }\end{array}$ & 96.3 & 0.46 & \\
\hline Pre-dorsal length & 85.7 & 0.41 & \\
\hline Pre-anal length & 133.1 & 0.64 & \\
\hline Caudal peduncle depth & 23.6 & 0.11 & \\
\hline $\begin{array}{l}\text { Caudal peduncle length (end of anal base to } \\
\text { end of } L_{\mathrm{S}} \text { ) }\end{array}$ & 32.6 & 0.16 & \\
\hline Dorsal fin base length & 106.3 & 0.51 & \\
\hline 6th dorsal fin spine (longest) & 21.3 & 0.10 & \\
\hline 4th dorsal fin ray (longest) & 19.4 & 0.09 & \\
\hline $\begin{array}{l}\text { Pectoral fin length (from dorsal insertion } \\
\text { point to end of longest ray) }\end{array}$ & 37.2 & 0.18 & \\
\hline Pectoral fin base length & 13.9 & 0.07 & \\
\hline Pelvic fin length & 35.1 & 0.17 & \\
\hline Pelvic fin base length & 11.7 & 0.06 & \\
\hline Anal fin base length & 51.0 & 0.24 & \\
\hline Caudal fin height (vertically extended) & 104.3 & 0.50 & \\
\hline
\end{tabular}


its biology and ecology are provided (Merella et al., 1998). Examination of our specimen revealed some of its biological aspects which we state only as indicating information since they are derived from a single specimen. Nevertheless, they provide useful information regarding the physical status of the specimen and help us state certain assumptions regarding its presence in the area.

Our specimen was found to be in good condition with no signs of starvation or stress-induced feeding suspension, as the large amount of food in its stomach and the existence of fatty tissue in the abdominal cavity revealed. This situation evidences favourable environmental conditions for the fish, also supported by the age of the specimen, since it is unlikely for a fish to survive for several years and retain a good condition in a stressful environment. This should also apply for the other three specimens caught in Annaba (Hemida et al., 2004), in St Tropez (Francour \& Mouine, 2008) and in the Ligurian Sea (Ligas et al., 2011), considering that they entered the Mediterranean during their juvenile stage. These specimens were not aged; however, since they were almost twice as large as our specimen we expect them to have been correspondingly older. Therefore, we could presume that this species presents no adaptation problems in the recent Mediterranean environment, at least regarding food acquisition and so, one of the fundamental prerequisites for its establishment in the area (i.e. food acquisition ability), is probably met.

Regarding the second prerequisite for the establishment of a self-sustained population in an area, i.e. successful spawning, our data are not sufficient to support any assumption. The gonads of our specimen were not developed and this could be either because the fish was far from its spawning period or due to its inability to spawn under the recent environmental conditions of the Mediterranean. Since there are no reproduction data for this species from any place of its natural distribution, at the moment we cannot hypothesize as to which of the above assumptions holds true. More specimens or future works on the reproduction of this species are needed to shed more light on this.

Regarding the origin of our individual, we consider three possibilities: (i) its presence is completely accidental and the fish has reached the area following the route of floating debris or algae during its early juvenile stage and settled in the vicinity of the area where it was caught, since the juveniles of this species are initially pelagic (Sgano, 1978) and are often related to flotsam (Tortonese, 1986; Bauchot, 1987; Castro et al., 1999); (ii) the specimen belongs to a population established on the north African Mediterranean coasts; (Hemida et al., 2004) reported a large number of specimens fished in Annaba), members of which occasionally move northwards, or the whole population is expanding northwards (such example of northward expansion of a south Mediterranean fish species is provided by Francour et al. 1994); or (iii) the specimen is a member of a small population already established in the area it was caught, or in an adjacent area. Verification of any of the above assumptions requires a more elaborate examination of the recent physicochemical conditions of the Mediterranean. Future sightings would contribute greatly and DNA comparisons could provide valuable evidence regarding the origin or the affinity of the specimens caught in different areas. Yet, whatever the origin of the specimens detected in the Mediterranean, the fact of the increased frequency of detections in the basin since 1996 stands out.
Evidence for the warming of the waters in the Mediterranean over the last decades and a shifting towards a more tropical regime has been provided by different authors (e.g. Schiano et al., 2005; Vargas-Yáñez et al., 2009). At the same time, increased frequency of detections of thermophilic Mediterranean species previously rare or absent in the colder north-western parts of the basin, has been recorded (Francour et al., 1994), along with a constantly increasing number of detections of alien species that enter the basin through the Suez Canal and the Gibraltar Strait (Quignard \& Tomasini, 2000; Ben Rais Lasram \& Mouillot, 2009). Notably, these detections present an increasing trend, with the rate of lessepsian fish introduction during 2000-2006 representing the highest value since the opening of the Suez Canal (Ben Rais Lasram \& Mouillot, 2009). In that sense, we could also consider the occurrence of this species in the Mediterranean and its eastern-wards range expansion in the basin as an indirect consequence of this tropicalization process, while the recently increased frequency of detections should also raise our awareness towards evidence that confirms the establishment of a population of this species in the basin.

\section{ACKNDWLEDGEMENTS}

The authors express their gratitude to Theodoros Margaris and Nikolaos Spyropoulos for providing the specimen and Dimitris Christodoulou for providing the detailed map of the area. We also thank Nota Peristraki for her valuable comments on the manuscript.

\section{REFERENCES}

Almada V.C., Henriques M. and Conçalves E.J. (1999) Ecology and behaviour of reef fishes in the temperate north-eastern Atlantic and adjacent waters. In Almada V.C., Oliviera R.F. and Conçalves E.J. (eds) Behaviour and conservation of littoral fishes. Lisboa: ISPA, pp. 33-69.

Ariola V. (1904) Pesci nuovi o rari per il golfo di Geova. Annali del Museo Civico di Storia Naturale di Genova, Ser. 31, 153-168. [In Italian.]

Bañón R. (2004) New records of two southern fish in Galician waters (NW Spain). Cybium 28, 367-368.

Bauchot M.L. (1987) Poissons osseux. In Fischer W. and Bauchot M.L. (eds) Fiches FAO d'identification des espèces pour les besoins de la pêche. Revision 1, Méditerrannée et Mer Noire. Zone de pêche 37. Volume 2. Vertébrés. Rome: FAO, pp. 893-1422.

Ben Rais Lasram F. and Mouillot D. (2009) Increasing southern invasion enhances congruence between endemic and exotic Mediterranean fish fauna. Biological Invasions 11, 697-711.

Canas A., Vasconcelos P., Lino P.G. and Santos M.N. (2005) Northernmost record of Kyphosus sectator (Osteichthyes: Kyphosidae) in the north-eastern Atlantic. Journal of the Marine Biological Association of the United Kingdom 85, 1535-1537.

Castro J.J., Santiago J.A. and Hernández-García V. (1999) Fish associated with fish aggregation devices off the Canary Islands (Central-East Atlantic). Scientia Marina 63, 191-198.

Cervigón F. (1993) Los peces marinos de Venezuela. Volume II. Caracas,Venezuela: Fundación Científica Los Roques.

Desoutter M. (1990) Kyphosidae. In Quero J.C., Hureau J.C., Karrer C., Post A. and Saldanha L. (eds) Check-list of the fishes of the eastern 
tropical Atlantic (CLOFETA). Volume II. Lisbon: JNICT; Paris: SEI and Paris: UNESCO, pp. 831-833.

Doderlein P. (1884) Rinvenimento di un pesce dell'esotico Genere Pimelepterus, Lac. nelle acque del Golgo di Palermo. Natutalista Siciliano $3,81-86$.

Dulčić J. and Ahnelt H. (2006) On the validity of the record of the Bermuda sea chub Kyphosus sectator (Kyphosidae) from the Adriatic Sea. Periodicum Biologorum 108, 231-233.

Francour P., Boudouresque C.F., Harmelin J.G., Harmelin-Vivien M.L. and Quignard J.P. (1994) Are the Mediterranean waters becoming warmer? Information from biological indicators. Marine Pollution Bulletin 28, 523-526.

Francour P. and Mouine N. (2008) First record of Kyphosus sectator (Kyphosidae) along the French Mediterranean coast. Cybium 32, $275-276$.

Hattour A. (2006) Première observation de la calicagère blanche Kyphosus sectatrix (Linnaeus, 1758) sur les côtes tunisienes. Bulletin de l'Institut National Scientifique et Technique de la Mer de Salammbô 33, 123-125.

Hemida F., Kanoun N., Golani D., Souissi J.B., Guélorget O. and Capapé C. (2004) Records of the Bermuda sea chub, Kyphosus sectator (Linnaeus, 1758) (Osteichthyes: Kyphosidae) from the coastal waters of Algeria (southern Mediterranean). Annals for Istrian and Mediterranean Studies, Series Historia Naturalis 14, 49-52.

Hubbs C.L. and Lagler K.F. (1958) Fishes of the Great Lakes Region. Ann Arbor, MI: University of Michigan Press.

Kocher T.D., Thomas W.K., Meyer A., Edwards S.V., Paabo S., Villablanca F.X. and Wilson A.C. (1989) Dynamics of mitochondrial DNA evolution in animals: amplification and sequencing with conserved primers. Proceedings of the National Academy of Sciences of the United States of America 86, 6196-6200.

Lebedev N.Y. (1946) Elementary populations of fish. Zoologichesky Zhurnal 25, 121-135. [In Russian.]

Ligas A., Sartor P., Sbrana M. and Ranieri S. de (2011) A new record of Kyphosus saltatrix (Pisces: Kyphosidae) along the Italian coasts (northwestern Mediterranean). Marine Biodiversity Records 4, e6.

Merella P., Massutí E. and Deudero S. (1998) On the occurrence of Kyphosus sectator (Osteichthyes: Kyphosidae) in the western Mediterranean. Journal of the Marine Biological Association of the United Kingdom 78, 687-69o.

Miller S.A., Dykes D.D. and Polesky H.F. (1988) A simple salting out procedure for extracting DNA from human nucleated cells. Nucleic Acids Research 16, 1215.

Nikolsky G.V. (1963) The ecology of fishes. London: Academic Press.
Palumbi S.R., Martin A., Romano S., Mcmillan W.O., Stice L. and Grabowski G. (1991) The simple fools guide to PCR, version II. Honolulu: University of Hawaii Press.

Prozorovskaya M.L. (1952) On the method of determining the fat content of the roach from the quantity of fat on the intestine. Bulletin of the Institute of Fisheries, USSR 1, 1-6. [In Russian.]

Quéro J.-C., Spitz J., Vayne J.-J., Auby I., Casamajor M.N., Leaute J.-P., Marie F., Monhurel L. and Quinquis J. (2009) Observations ichthyologiques éffectuées en 2008. Annales de la Société des Sciences Naturelles de la Charente-Maritime 9, 932-940.

Quignard J.-P. and Tomasini J.A. (2000) Mediterranean fish biodiversity. Biologia Marina Mediterranea 7, 1-66.

Robins C.R. and Ray G.C. (1986) A field guide to Atlantic coast fishes of North America. Boston, USA: Houghton Mifflin Company.

Schiano M.E., Sparnocchia S., Cappa C. and Bozzano R. (2005) An analysis of the climate variability over the Mediterranean Sea by means of the surface water vapour density. International Journal of Climatology 25, 1731-1748.

Scott W.B. and Scott M.G. (1988) Atlantic fishes of Canada. Canadian Bulletin of Fisheries and Aquatic Sciences 219, 731 p.

Sgano T. (1978) Kyphosidae. In Fischer W. (ed.) FAO species identification sheets for fishery purposes. Western central Atlantic (Fishing Area 31). Volume III. Rome: FAO.

Tortonese E. (1986) Kyphosidae. In Whitehead P.J.P., Bauchot M.-L., Hureau J.-C., Nielsen J. and Tortonese E. (eds) Fishes of the northeastern Atlantic and the Mediterranean. Paris: UNESCO, pp. 912-913.

Vargas-Yáñez M., Moya F., Tel E., García-Martínez M.C., Guerber E. and Bourgeon M. (2009) Warming and salting in the western Mediterranean during the second half of the 2oth century: inconsistencies, unknowns and the effect of data processing. Scientia Marina 73, $7-28$.

and

Zhang Z., Schwartz S., Wagner L. and Miller W. (2000) A greedy algorithm for aligning DNA sequences. Journal of Computational Biology 7 , 203-214.

Correspondence should be addressed to

S. Kiparissis

Department of Aquaculture and Fisheries Management

Technological Educational Institute of Messolonghi

Nea Ktiria

30200 Messolonghi

Greece

email: skiparis@teimes.gr 